Phase Stability of the Mixed-Conducting Sr-Fe-Co-O System*

B. Ma and U. Balachandran

Energy Technology Division, Argonne National Laboratory

Argonne, Illinois 60439

J. P. Hodges, J. D. Jorgensen, and D. J. Miller

Materials Science Division, Argonne National Laboratory

Argonne, Illinois 60439

J. W. Richardson, Jr.

Intense Pulsed Neutron Source, Argonne National Laboratory

Argonne, Illinois 60439

November 1997

The submitted manuscript has been created by the
University of Chicago as Operator of Argonne
National Laboratory "Argonne") under Contract No.
W-31-109-ENG-38 with the U.S. Department of
Energy. The U.S. Government retains for itself, and
others acting on its behalf, a paid-up, nonexclusive,
irrevocable worldwide license in said article to
reproduce, prepare derivative works, distribute copies
to the public, and perform publicly and display
publicly, by or on behalf of the Government.

For submittal to the Materials Research Society fall meeting, Boston, MA, December 1-5, 1997.

*Work at Argonne is supported by the U.S. Department of Energy, Federal Energy Technology Center, under Contract W-31-109-Eng-38. 


\section{DISCLAIMER}

This report was prepared as an account of work sponsored by an agency of the United States Government. Neither the United States Government nor any agency thereof, nor any of their employees, make any warranty, express or implied, or assumes any legal liability or responsibility for the accuracy, completeness, or usefulness of any information, apparatus, product, or process disclosed, or represents that its use would not infringe privately owned rights. Reference herein to any specific commercial product, process, or service by trade name, trademark, manufacturer, or otherwise does not necessarily constitute or imply its endorsement, recommendation, or favoring by the United States Government or any agency thereof. The views and opinions of authors expressed herein do not necessarily state or reflect those of the United States Government or any agency thereof. 


\section{DISCLAIMER}

Portions of this document may be illegible in electronic image products. Images are produced from the best available original document. 


\title{
PHASE STABILITY OF THE MIXED-CONDUCTING Sr-Fe-Co-O SYSTEM
}

\author{
B. Ma*, U. Balachandran*, J.P. Hodges $\dagger$, J.D. Jorgensen ${ }^{\dagger}$, D.J. Miller ${ }^{\dagger}$, and J.W. Richardson, Jr. $\ddagger$ \\ *Energy Technology Division, Argonne National Laboratory, Argonne, Illinois 60439 \\ †Materials Science Division, Argonne National Laboratory, Argonne, Illinois 60439 \\ \$Intense Pulsed Neutron Source, Argonne National Laboratory, Argonne, Illinois 60439
}

\section{ABSTRACT}

Mixed-conducting ceramic oxides have potential uses in high-temperature electrochemical applications such as solid oxide fuel cells, batteries, sensors, and oxygen-permeable membranes. The Sr-Fe-Co-O system combines high electronic/ionic conductivity with appreciable oxygen permeability at elevated temperatures. Dense ceramic membranes made of this material can be used to separate high-purity oxygen from air without the need for external electrical circuitry, or to partially oxidize methane to produce syngas. Samples of $\mathrm{Sr}_{2} \mathrm{Fe}_{3-\mathrm{x}} \mathrm{Co}_{\mathrm{x}} \mathrm{O}_{\mathrm{y}}$ (with $\mathrm{x}=0,0.6,1.0$, and 1.4) were prepared by solid-state reaction method in atmospheres with various oxygen partial pressures $\left(\mathrm{pO}_{2}\right)$ and were characterized by X-ray diffraction, scanning electron microscopy, and electrical conductivity testing. Phase components of the sample are dependent on cobalt concentration and $\mathrm{pO}_{2}$. Electrical conductivity increases with increasing temperature and cobalt content in the material.

\section{INTRODUCTION}

Recently, oxides with mixed electronic and ionic conductivities have begun to attract attention because of their applications in high-temperature electrochemical processes [1-5]. For example, they are used as electrodes in solid oxide fuel cells, and if their oxygen permeability is high enough, they can be used as oxygen-separation membranes. Sr-Fe-Co-O has not only high combined electronic and oxygen ionic conductivity but also oxygen permeability that is superior to that of other reported ceramic oxides [6-11]. It is a good candidate material as a dense membrane for separation of high-purity oxygen. In an oxygen separation reactor, oxygen can be transported from the high oxygen partial pressure $\left(\mathrm{pO}_{2}\right)$ side to the low- $\mathrm{pO}_{2}$ side under the driving force of the $\mathrm{pO}_{2}$ difference, $\Delta \log \left(\mathrm{pO}_{2}\right)$, without the need for external electric circuitry. Balachandran et al. [7] demonstrated that extruded membrane tubes made of $\mathrm{Sr}-\mathrm{Fe}-\mathrm{Co}$ oxide can be used for partial oxidation of methane to produce syngas $\left(\mathrm{CO}+\mathrm{H}_{2}\right)$ in a methane conversion reactor that operates at $\approx 850^{\circ} \mathrm{C}$. In this type of reactor, oxygen on one side of the membrane was separated from air on the other side of the membrane. Methane conversion efficiencies of $>98 \%$ were observed and the reactor tubes have operated for $>1000 \mathrm{~h}$. Moreover, the oxygen flux obtained from the separation of air in this type of conversion reactor is considered commercially feasible. The use of this technology can significantly reduce the cost of oxygen separation [12].

To obtain sufficient oxygen flux, the gas separation reactor must be operated at high temperatures and substantial $\mathrm{pO}_{2}$ differences. Therefore, stability of the ceramic membranes is an important issue. Certain compounds of $\mathrm{SrFe}_{1-\mathrm{x}} \mathrm{Co}_{\mathrm{x}} \mathrm{O}_{3-\delta}$ were found unsuitable for use in gas separation because they lack stability in highly reducing environments [13]. Thermodynamic calculations can normally give us accurate data on the stability of a system. However, certain 
examples of discrepancies between the calculated thermodynamic stability and the actual results indicate the importance of obtaining supporting data from real systems [14].

In this paper, we report our studies on the structural and phase stability of $\mathrm{Sr}_{2} \mathrm{Fe}_{3-\mathrm{x}} \mathrm{Co}_{\mathrm{x}} \mathrm{O}_{\mathrm{y}}$ materials in air and reducing argon environments. In-situ electrical conductivity and ex-situ roomtemperature X-ray diffraction (XRD) and scanning electron microscopy (SEM) experiments were used to characterize the material.

\section{EXPERIMENTAL}

The $\mathrm{Sr}_{2} \mathrm{Fe}_{3-\mathrm{x}} \mathrm{Co}_{\mathrm{x}} \mathrm{O}_{\mathrm{y}}$ (with $\mathrm{x}=0,0.6,1.0$, and 1.4) powders were made by a solid-state reaction method, with appropriate amounts of $\mathrm{SrCO}_{3}, \mathrm{Co}\left(\mathrm{NO}_{3}\right)_{2} \cdot 6 \mathrm{H}_{2} \mathrm{O}$, and $\mathrm{Fe}_{2} \mathrm{O}_{3}$; mixing and grinding were conducted in isopropanol with zirconia media for $10 \mathrm{~h}$. After drying, the mixture was calcined in air at $850^{\circ} \mathrm{C}$ for $16 \mathrm{~h}$, with intermittent grinding. After final calcination, the powder was ground with an agate mortar and pestle to an average particle size of $\approx 7 \mu \mathrm{m}$. The resulting powder was pressed uniaxially with a 1200 -MPa load into bars $7.5 \mathrm{~mm}$ wide, $44 \mathrm{~mm}$ long, and $\approx 5 \mathrm{~mm}$ thick. The bars were then sintered in air at $\approx 1200^{\circ} \mathrm{C}$ for $5 \mathrm{~h}$. The true density was measured on powder with an AccuPyc 1330 pycnometer. Bulk density was determined by the Archimedean method, with isopropanol as the liquid medium. Calculated relative density of air-sintered $\mathrm{SrFeCo}_{0.5} \mathrm{O}_{\mathrm{X}}$ samples was $\approx 95 \%$ of theoretical value. Thin bars $\approx 1 \times 5 \times 20 \mathrm{~mm}^{3}$ were cut from the samples and subjected to postannealing heat treatment in various low- $\mathrm{pO}_{2}$ environments at $900-1100^{\circ} \mathrm{C}$.

Room-temperature X-ray powder diffraction analysis was carried out with a Scintag XDS-2000 diffractometer. Data were taken with $\mathrm{Cu} \mathrm{K}_{\alpha}$ radiation. A high-purity intrinsic Ge energy-dispersive detector was used to minimize background due to sample fluorescence. A continuous scan with a $2 \theta$ scanning rate of $1 \% \mathrm{~min}$ and chopping step of $0.03^{\circ}$ was used to collect data. SEM observations were conducted with a JEOL JSM-5400 scanning microscope at an accelerating voltage of $20 \mathrm{KeV}$.

Conductivity of the sample was determined by the four-probe method. Platinum wires were attached to the specimen bar to serve as current and voltage leads. Resistance of the specimen was measured with an HP 4192A LF impedance analyzer at $23 \mathrm{~Hz}$. Details of the experimental configuration for measuring conductivity were reported earlier [10]. A K-type thermocouple was attached to an yttria-stabilized zirconia (YSZ) plate on which the sample bars were placed for the heat treatments. The thermocouple was used for both controlling and detecting the temperature of the programmable electric furnace. Temperature tolerance within the uniform hot zone of the furnace is $\pm 1^{\circ} \mathrm{C}$. Desirable gaseous environments were obtained by flowing premixed gases through the system during the experiments.

\section{RESULTS AND DISCUSSIONS}

Room-temperature XRD patterns of air-sintered $\mathrm{Sr}_{2} \mathrm{Fe}_{3-\mathrm{x}} \mathrm{Co}_{\mathrm{x}} \mathrm{O}_{\mathrm{y}}$ are plotted in Fig. 1 for different $x$ values. The powder XRD pattern of the $x=0$ composition (Fig. 1a) agrees with the result reported for a single crystal $\mathrm{Sr}_{4} \mathrm{Fe}_{6} \mathrm{O}_{13}$ sample [15]. For comparison, the XRD pattern of the perovskite phase $\mathrm{SrFe}_{0.8} \mathrm{Co}_{0.2} \mathrm{O}_{\mathrm{x}}$ is plotted in Fig. 1e. Air-sintered $\mathrm{Sr}_{2} \mathrm{Fe}_{2} \mathrm{CoO}_{\mathrm{y}}(\mathrm{x}=1$, Fig. 1c) is a multiple phase material, with $\approx 40 \%$ perovskite phase, as obtained from Rietveld analysis [16]. Airsintered $\mathrm{Sr}_{2} \mathrm{Fe}_{2.4} \mathrm{Co}_{0.6} \mathrm{O}_{\mathrm{y}}(\mathrm{x}=0.6$, Fig. $1 \mathrm{~b})$ contains less than $3 \%$ perovskite phase, while airsintered $\mathrm{Sr}_{2} \mathrm{Fe}_{1.6} \mathrm{Co}_{1.4} \mathrm{O}_{\mathrm{y}}(\mathrm{x}=1.4$, Fig. 1d) has more than $90 \%$ perovskite phase. Traces of cobalt 


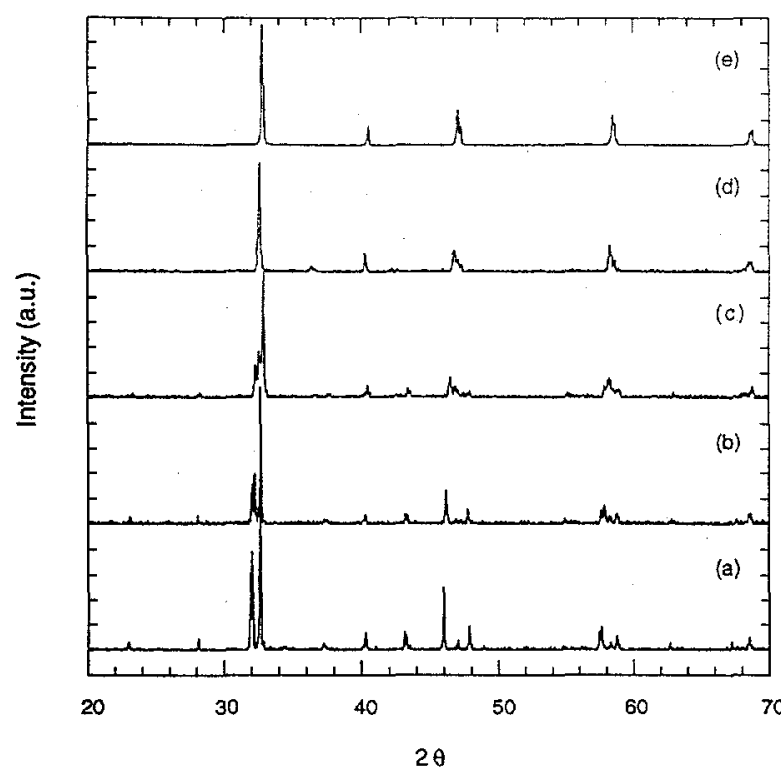

Fig. 1. Room-temperature X-ray diffraction patterns of air-sintered samples: (a) $\mathrm{Sr}_{2} \mathrm{Fe}_{3} \mathrm{O}_{y}$, (b) $\mathrm{Sr}_{2} \mathrm{Fe}_{2.4} \mathrm{Co}_{0.6} \mathrm{O}_{\mathrm{y}}$, (c) $\mathrm{Sr}_{2} \mathrm{Fe}_{2} \mathrm{CoO}_{\mathrm{y}}$ (d) $\mathrm{Sr}_{2} \mathrm{Fe}_{1.6} \mathrm{Co}_{1.4} \mathrm{O}_{\mathrm{y}}$, and (e) $\mathrm{SrFe}_{0.8} \mathrm{Co}_{0.2} \mathrm{O}_{\mathrm{y}}$.

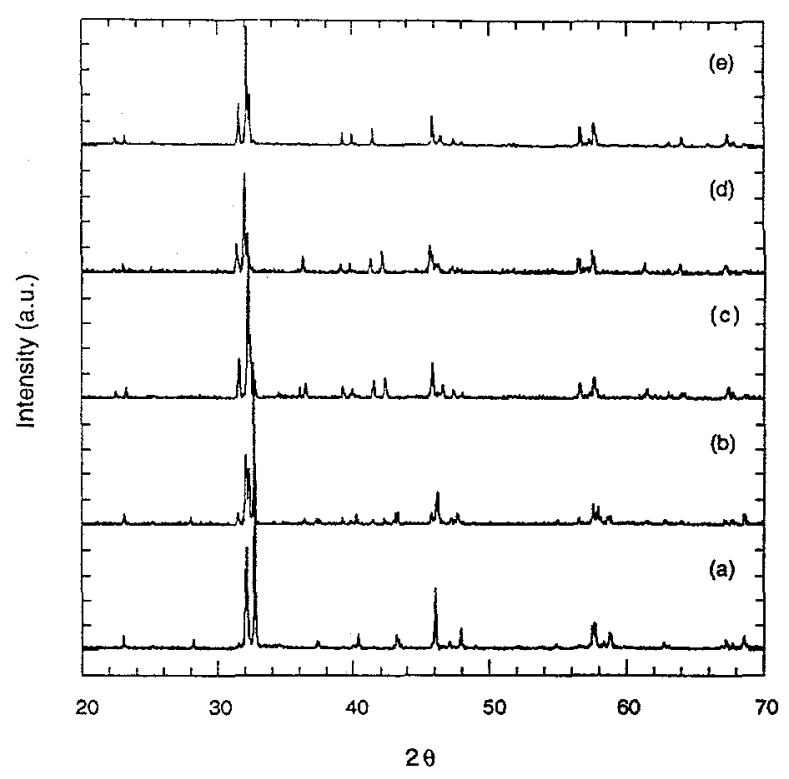

Fig. 2. Room-temperature $\mathrm{X}$-ray diffraction patterns of argon-annealed samples: (a) $\mathrm{Sr}_{2} \mathrm{Fe}_{3} \mathrm{O}_{y}$, (b) $\mathrm{Sr}_{2} \mathrm{Fe}_{2.4} \mathrm{Co}_{0.6} \mathrm{O}_{\mathrm{y}}$, (c) $\mathrm{Sr}_{2} \mathrm{Fe}_{2} \mathrm{CoO}_{\mathrm{y}}$, (d) $\mathrm{Sr}_{2} \mathrm{Fe}_{1.6} \mathrm{Co}_{1.4} \mathrm{O}_{\mathrm{y}}$, and (e) $\mathrm{SrFe}_{0.8} \mathrm{Co}_{0.2} \mathrm{O}_{\mathrm{y}}$.
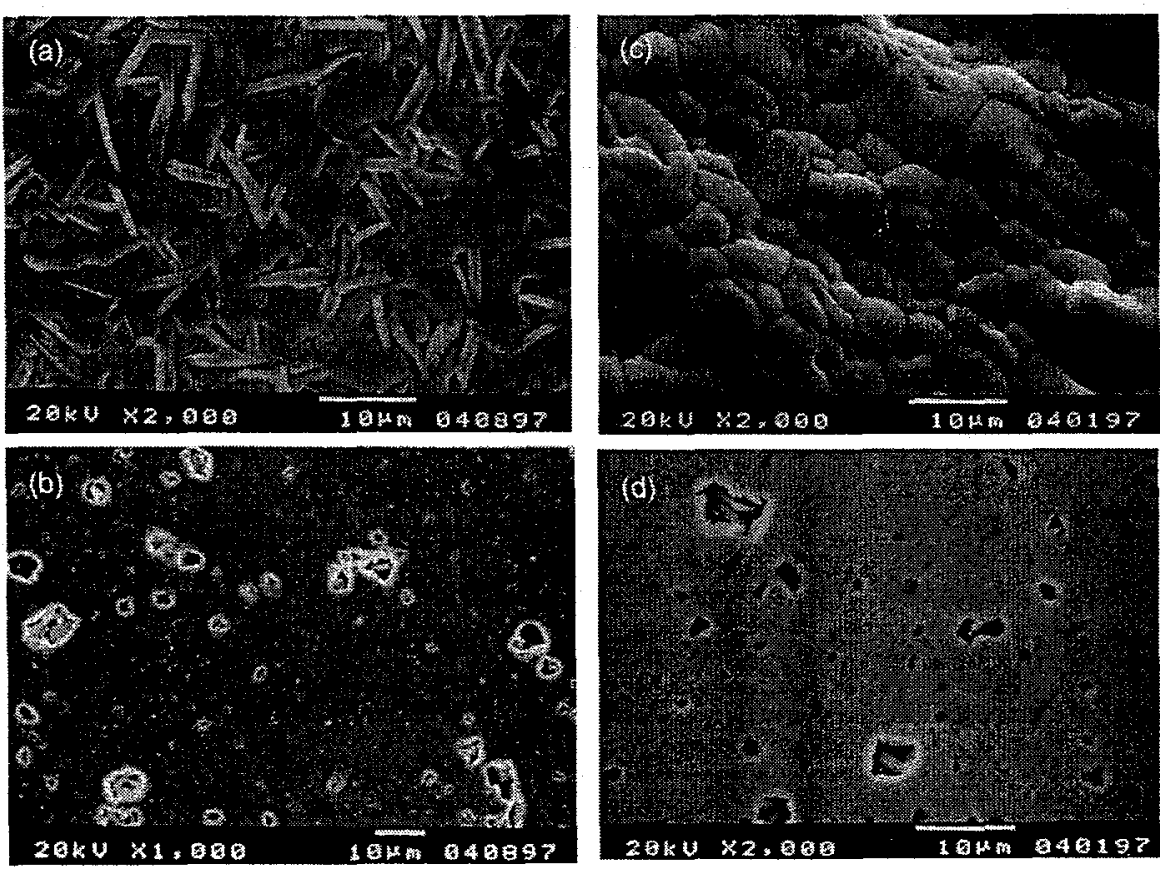

Fig. 3. SEM morphology of $\mathrm{Sr}_{2} \mathrm{Fe}_{2} \mathrm{CoO}_{\mathrm{x}}$ sample: (a) original surface of air-sintered sample, (b) polished surface of air-sintered sample, (c) original surface of argonannealed sample, (d) polished surface of argon-annealed sample. 
oxide impurity phase were also observed in the $\mathrm{Sr}_{2} \mathrm{Fe}_{1.6} \mathrm{Co}_{1.4} \mathrm{O}_{\mathrm{y}}$ sample. XRD patterns of the argon-annealed samples are shown in Fig. 2. At high temperatures, the perovskite phase can be reduced to the brownmillerite structure [17] in the reducing argon environment ( $\left.\mathrm{pO}_{2} \approx 10^{-6} \mathrm{~atm}\right)$. The argon-annealed $\mathrm{Sr}_{2} \mathrm{Fe}_{3} \mathrm{O}_{\mathrm{y}}(\mathrm{x}=0$, Fig. 2a) has the same structure as that of the air-sintered sample and contains no brownmillerite phase, although other argon-annealed cobalt-containing samples all consist of brownmillerite phase. Content of the brownmillerite phase in annealed $\mathrm{Sr}_{2} \mathrm{Fe}_{3-\mathrm{x}} \mathrm{Co}_{\mathrm{x}} \mathrm{O}_{\mathrm{y}}$ increases with increasing $\mathrm{x}$, as shown in Fig. $2 \mathrm{~b}, 2 \mathrm{c}$, and $2 \mathrm{~d}$. The cobalt oxide phase can be seen clearly in the cobalt-content samples. XRD of a pure brownmillerite phase of the argon-annealed $\mathrm{SrFe}_{0.8} \mathrm{Co}_{0.2} \mathrm{O}_{\mathrm{x}}$ sample is shown in Fig. 2e for comparison. Details on crystal structure of the $\mathrm{Sr}_{2} \mathrm{Fe}_{3-\mathrm{x}} \mathrm{Co}_{\mathrm{x}} \mathrm{O}_{\mathrm{y}}$ samples will be reported elsewhere [18]. The lattice parameters of air-sintered $\mathrm{Sr}_{2} \mathrm{Fe}_{3-\mathrm{x}} \mathrm{Co}_{\mathrm{x}} \mathrm{O}_{\mathrm{y}}$ samples are listed in Table 1.

Table 1. Lattice Parameters of the Air -Sintered $\mathrm{Sr}_{2} \mathrm{Fe}_{3-\mathrm{x}} \mathrm{Co}_{\mathrm{x}} \mathrm{O}_{\mathrm{y}}$ samples

\begin{tabular}{c|cc}
\hline Cobalt Content $\mathrm{x}$ & Phases Components & Lattice Parameters: $\mathrm{a}, \mathrm{b}, \mathrm{c}(\AA)$ \\
\hline 0.0 & $\mathrm{O}(>99 \%)$ & $11.126,18.978,5.5864$ \\
0.3 & $\mathrm{O}(>95 \%)+\mathrm{P}(<5 \%)$ & $11.081,19.008,5.5649$ \\
0.6 & $\mathrm{O}(>90 \%)+\mathrm{P}(<10 \%)$ & $11.065,19.008,5.5618$ \\
1.0 & $\mathrm{O}(>75 \%)+\mathrm{P}(<25 \%)$ & $11.017,19.030,5.5463$ \\
\hline
\end{tabular}

SEM images of the air-sintered and argon-annealed $\mathrm{Sr}_{2} \mathrm{Fe}_{2} \mathrm{CoO}_{\mathrm{y}}$ sample are shown in Fig. 3; they reveal a dense homogeneous structure for both samples. Energy-dispersive X-ray (EDX) elemental analysis showed that the overall atomic ratio of the metal elements is consistent with that given in the chemical formula. The polished-surface SEM images showed that the argon-annealed sample is denser and contains fewer pores than the air-sintered sample. Spherical cobalt-rich phase was identified in the argon-annealed sample. By correlating SEM observation with XRD results, we identified the spherical phase as cobalt oxide (CoO, JCPD No. 9-402).

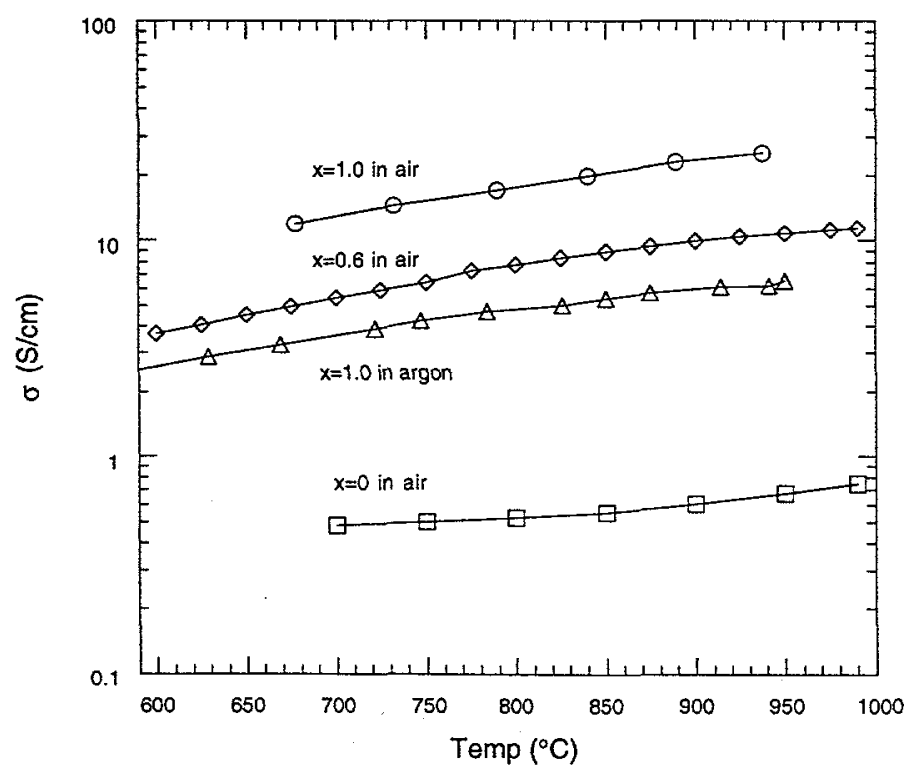

Fig. 4. Temperature dependence of $\mathrm{Sr}_{2} \mathrm{Fe}_{3-\mathrm{x}} \mathrm{Co}_{\mathrm{x}} \mathrm{O}_{\mathrm{y}}$ samples. 
The total conductivity of $\mathrm{Sr}_{2} \mathrm{Fe}_{3-\mathrm{x}} \mathrm{Co}_{\mathrm{x}} \mathrm{O}_{\mathrm{y}}$ sample is shown in Fig. 4 as a function of temperature. Conductivity increases as temperature and cobalt content increase. At $900^{\circ} \mathrm{C}$, the conductivity of $\mathrm{Sr}_{2} \mathrm{Fe}_{2} \mathrm{CoO}_{\mathrm{y}}$ is $\approx 20$ and $\approx 6 \mathrm{~S} \cdot \mathrm{cm}^{-1}$ in flowing air and argon environments, respectively. Conductivities of $\mathrm{Sr}_{2} \mathrm{Fe}_{2.4} \mathrm{Co}_{0.6} \mathrm{O}_{\mathrm{y}}$ and $\mathrm{Sr}_{2} \mathrm{Fe}_{3} \mathrm{O}_{\mathrm{y}}$ are $\approx 10$ and $\approx 0.6 \mathrm{~S} \cdot \mathrm{cm}^{-1}$, respectively, at $900^{\circ} \mathrm{C}$ in air. Figure 5 shows the transient conductivity of the $\mathrm{Sr}_{2} \mathrm{Fe}_{2} \mathrm{CoO}_{\mathrm{y}}$ sample at $950^{\circ} \mathrm{C}$ after its surrounding atmosphere was changed. The conductivity recovered to its original value after the surrounding atmosphere was switched back to air from the reducing argon environment. This indicates that a phase transition in $\mathrm{Sr}_{2} \mathrm{Fe}_{2} \mathrm{CoO}_{y}$ is reversible after the surrounding atmosphere is changed.

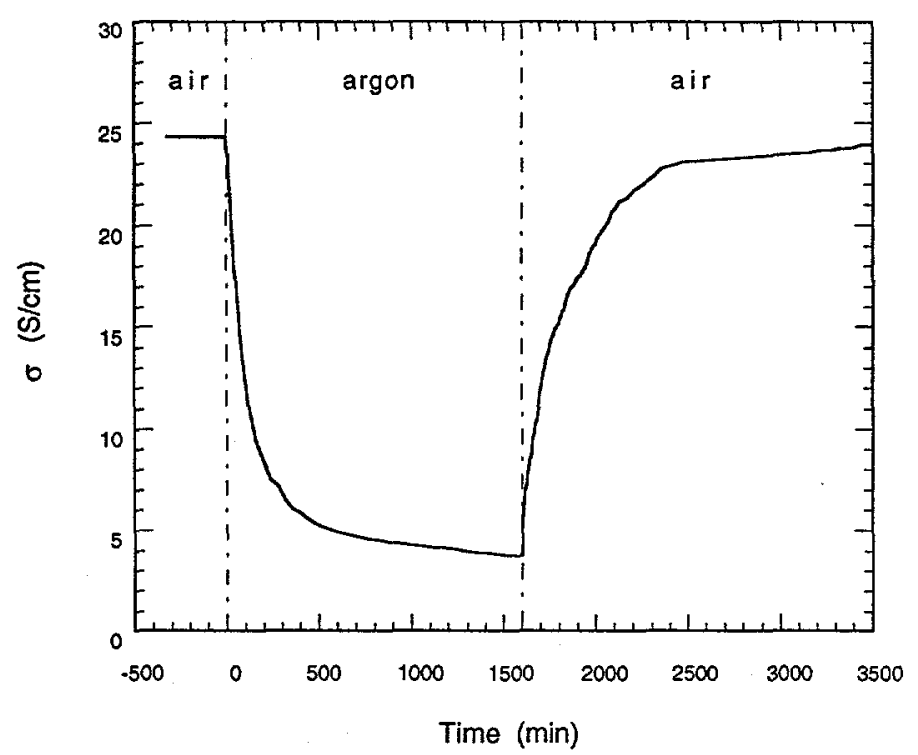

Fig. 5. Conductivity transient behavior of $\mathrm{Sr}_{2} \mathrm{Fe}_{2} \mathrm{CoO}_{\mathrm{y}}$ sample at $950^{\circ} \mathrm{C}$.

\section{CONCLUSIONS}

Phase components of $\mathrm{Sr}_{2} \mathrm{Fe}_{3-\mathrm{x}} \mathrm{Co}_{\mathrm{x}} \mathrm{O}_{\mathrm{y}}$ are strongly dependent on the cobalt content in the sample. The $\mathrm{Sr}_{2} \mathrm{Fe}_{3} \mathrm{O}_{\mathrm{y}}$ sample is single-phase material, while the high-cobalt-content samples $(\mathrm{x}>$ $0.6)$ contain multiple phases. Perovskite phase in the high-cobalt-content samples increases with increasing cobalt content. In a reducing argon environment, the single-phase $\mathrm{Sr}_{2} \mathrm{Fe}_{3} \mathrm{O}_{\mathrm{y}}$ sample has the same crystal structure as the air-sintered sample, while the brownmillerite phase was observed in the cobalt-containing samples. Cobalt oxide has also been found in the argon-annealed cobalt containing samples.

Total conductivity of $\mathrm{Sr}_{2} \mathrm{Fe}_{3-\mathrm{x}} \mathrm{Co}_{\mathrm{x}} \mathrm{O}_{\mathrm{y}}$ increases with increasing temperature and cobalt content in the sample. At $900^{\circ} \mathrm{C}$, the conductivity of $\mathrm{Sr}_{2} \mathrm{Fe}_{2} \mathrm{CoO}_{\mathrm{y}}$ is $\approx 20$ and $\approx 6 \mathrm{~S} \cdot \mathrm{cm}^{-1}$ in flowing air and argon environments, respectively. The conductivities of $\operatorname{Sr}_{2} \mathrm{Fe}_{2.4} \mathrm{Co}_{0.6} \mathrm{O}_{\mathrm{y}}$ and $\mathrm{Sr}_{2} \mathrm{Fe}_{3} \mathrm{O}_{\mathrm{y}}$ are $\approx 10$ and $\approx 0.6 \mathrm{~S} \cdot \mathrm{cm}^{-1}$, respectively, at $900^{\circ} \mathrm{C}$ in air. Transient conductivity behavior of the sample, after surrounding atmosphere is switched back and forth, indicates that the phase transition in the materials is reversible. 


\section{ACKNOWLEDGMENT}

Work at Argonne is supported by the U.S. Department of Energy, Federal Energy Technology Center, under Contract W-31-109-Eng-38.

\section{REFERENCES}

1. T. Takahashi and H. Iwahara, Energy Convers., 11, 105 (1971).

2. B. C. H. Steele, Mater. Sci. Eng. B-Solid State M., 13, 79 (1992).

3. N. Q. Minh, J. Am. Ceram. Soc., 76, 563 (1993).

4. R. DiCosimo, J. D. Burrington, and R. K. Grasselli, J. Catal., 102, 377 (1992).

5. K. R. Kendall, C. Navas, J. K. Thomas, and H.-C. Loye, Solid State Ionics, 82, 215 (1995).

6. U. Balachandran, S. L. Morissette, J. T. Dusek, R. L. Mieville, R. B. Poeppel, M. S. Kleefisch, S. Pei, T. P. Kobylinski, and C. A. Udovich, Proc. Coal Liquefaction and Gas Conversion Contractor Review Conf., S. Rogers et al., eds., Vol. 1, pp. 138-160, U.S. Dept. of Energy, Pittsburgh Energy Technology Center (1993).

7. U. Balachandran, T. J. Dusek, S. M. Sweeney, R. B. Poeppel, R. L. Mieville, P. S. Maiya, M. S. Kleefisch, S. Pei, T. P. Kobylinski, C. A. Udovich, and A. C. Bose, Am. Ceram. Soc. Bull., 74, 71 (1995).

8. Y. Teraoka, H. M. Zhang, S. Furukawa, and N. Yamozoe, Chem. Lett., 1985, 1734 (1985).

9. Y. Teraoka, T. Nobunaga, and N. Yamazoe, Chem. Lett., 1988, 503 (1988).

10. B. Ma, J.-H. Park, C. U. Segre, and U. Balachandran, Mater. Res. Soc. Symp. Proc., 393, 49 (1995).

11. B. Ma, U. Balachandran, C.-C. Chao, J.-H. Park, and C. U. Segre, Ceram. Trans. Series, 73, 169 (1997).

12. U. Balachandran, J. T. Dusek, P. S. Maiya, R. L. Mieville, B. Ma, M. S. Kleefisch, and C. A. Udovich, presented at 11th Intersociety Cryogenic Symp., Energy Week Conf. \& Exhibition, Houston, Jan. 28-30, 1997.

13. S. Pei, M. S. Kleefisch, T. P. Kobylinski, J. Faber, C. A. Udovich, V. Zhang-McCoy, B.

Dabrowski, U. Balachandran, R. L. Mieville, and R. B. Poeppel, Catal. Lett., 30, 201 (1995).

14. H. Iwahara, H. Uchida, K. Morimoto, and S. Hosgoi, J. Appl. Electrochem., 19, 448 (1989).

15. A. Yoshiasa, K. Ueno, F. Kanamaru, and H. Horiuchi, Mater. Res. Bull, 21, 175 (1986).

16. H. M. Rietveld, J. Appl. Cryst., 2, 65 (1969).

17. C. Greaves, A. J. Jacobson, B. C. Tofield, and B. E. F. Fender, Acta Cryst., B31, 641 (1975).

18. J. P. Hodges, J. D. Jorgensen, D. J. Miller, B. Ma, U. Balachandran, and J. W. Richardson, Jr., this proceedings. 